\title{
Developing the Interactive e-Module Based on Integrated Learning for Primary School Students
}

\author{
Risda Amini and Usmeldi
}

\begin{abstract}
In the 2013 curriculum subjects in primary schools were organized with themes, namely combining all subjects that reflect students' everyday lives. However, the themes in the student's book do not integrate one subject with the others and do not reflect the students real life. Therefore, it is hard for many primary school teachers in Padang to implement the integrated learning using the textbooks. This research aims to develop the interactive e-module based on the principles of integrated learning that can facilitate students in carrying out learning process, so it can improve students' competency. The research and development of interactive e-module use four-D models that consist of four stages, namely define, design, develop and disseminate. The research subject was the interactive e-module based on integrated learning. The respondents of this research were 12 teachers and 70 Grade 5 students of three primary schools in Padang, West Sumatra, Indonesia. Data were collected using observation sheets, interview guides, questionnaires, and tests. There are three main results obtained from the research. First, according to expert judgment the interactive e-module is valid. Second, based on teacher and student's responses the module is very practical. Third, based on the student learning outcomes the interactive e-module is effective.
\end{abstract}

Index Terms - Interactive e-module, integrated learning, student competency.

\section{INTRODUCTION}

Various efforts have been made to improve education quality, including the establishment of eight national education standards. Three of the national standards of education are content standards, graduate competency standards, and process standards which become a reference in the implementation of education. The 2013 curriculum emphasizes graduates have high competency and good characters. The graduates are expected to possess related skill and knowledge integrated with the learning materials. One of the demands outlined in the 2013 curriculum is implementing student-centered combined with the scientific approach.

The subjects in primary school are organized in themes, which are integrated with all primary school subjects. To support the implementation of the 2013 curriculum, the Indonesian government has provided the students with a textbook. Within the framework of the 2013 curriculum, the teacher is a facilitator, motivator, and one of the alternative sources of learning. Teachers design the instructional materials based on the curriculum demands, so that students can master the competencies. However, the fact is that many

Manuscript received July 25, 2021; revised October 26, 2021. This work was supported in part by Universitas Negeri Padang, Indonesia.

Risda Amini and Usmeldi are with Universitas Negeri Padang, Indonesia (e-mail: risdamini@yahoo.co.id, usmeldy@yahoo.co.id). teachers have limited experience in teaching integrated activities, such as scientific inquiry and are less able to apply the early conception from which the process of scientific knowledge is produced [1]. The teachers often face difficulties in implementing thematic learning [2].

Every student must have competence in three aspects, they are attitudes, knowledge and skills. In the attitudes aspect, the most important indicator is the faithful and devoted attitude to God which is also included in spirituals value indicator. In this aspect of attitude, students are given an understanding of the universe of science that will cultivate attitudes of admiration in God and add to the belief in God's supremacy based on the beauty embodied in the rule of God's created nature. This attitude can be developed in the learning materials obtained in the primary school. The learning materials that will be studied by students can be presented in the form of a student book [3].

The student book is the instructional media, educational strategy, and regarded as reference books compulsory in the delivery of teaching materials. An excellent student book must follow the structure that matches the characteristic of the 2013 curriculum. Therefore, developing student book based on the 2013 curriculum was carried out to achieve the goals of national education and designing and developing the student book must follow the rules or principles specified.

The needs analysis found that the student book used in primary school has not yet reached expectations and students' activities on the book are not yet found. The suitability of the student book with the Standard of Graduate Competency on the aspects of attitude and skills is lacking. The student book tends to show only certain aspects of knowledge. A good student book should be expected to able to create interactions between books, students, and teachers. In the existing student book, some themes in one subject are still not integrated with other subjects. The result of the analysis of the book also shows the mapping of Basic Competence on each sub-theme does not contain all the Basic Competences that must exist. The formulation of learning objectives does not include the attitude aspect. The attitude aspect can be seen from the achievement of students learning outcomes of primary schools. The data in Table I shows the students' learning competencies, including sufficient categories, meaning that most of the students have yet to understand the learning materials.

Based on the observation results carried out towards primary schools students in Padang who learn by using the student book, it is found that student's book has not been able to involve students actively in learning the theme so that many students have difficulty answering the questions and completing the tasks. The students are told to find solutions 
through the internet. The reality shows that only a small percentage of teachers and students can access the internet.

TABLE I: STUDENT COMPETENCIES BEFORE USING THE INTEGRATED MODEL

\begin{tabular}{cccc}
\hline \multirow{2}{*}{ Domain } & \multicolumn{3}{c}{ Primary School (SD) } \\
\cline { 2 - 4 } & SD 03 & SD 05 & SD 51 \\
\hline Attitude & 61.2 & 65.3 & 58.0 \\
Skill & 66.8 & 67.2 & 63.5 \\
Knowledge & 70.1 & 72.6 & 68.6 \\
\hline \hline
\end{tabular}

The student book available shows the uniformity of text and context of themes and subject matter for all primary schools in urban and rural areas across Indonesia. This is not based on the integrated learning as required in the 2013 curriculum, that is using themes to connect some subject content with students' real-life experiences [4]. Students' real-life experiences vary from region to another region, consequently, the student book must be adapted to the conditions of each region.

One of the concrete steps to solve the problem of student books is to develop interactive e-modules that fulfill the needs of students and can also involve them actively in learning. Interactive e-modules are highly needed to help students learn during this Covid-19 pandemic. Students can learn at home independently. Until now there has been no research on the development of the interactive e-module based on the integrated learning principles for primary school students.

The development of interactive e-modules has been carried out by previous researchers by implementing various learning models, namely the project based learning [5], contextual teaching and learning [6], problem based learning [7], guided inquiry [8], and inquiry [9]. In addition, interactive e-modules have also been developed by previous researchers by using various approaches, namely RASA (resources, activities, supports, and assessments) [10], CASE (creative, active, systematic, and effective) [11], web [12], and SETS (Science, Environment, Technology, Society) [13] The design and characteristics of this interactive e-module refers to the model or approach used. All the interactive e-modules that have been developed have not integrated the themes of primary schools students' real life, as required by the 2013 curriculum.

Interactive e-modules need to be developed using appropriate learning models. One way to facilitate students in learning is through an integrated learning model. Integrated learning means combining various aspects of the domain attitude, knowledge, and skills [14]. Integrated learning provides opportunities for students to develop thinking skills, process skills, and scientific attitudes. Integrated learning uses themes to link between some subject content and the students' real-life experiences, to provide meaningful experiences to them. The integrated learning could motivate students to learn and develop scientific character [15]. The scientific character was characterized by high curiosity, ability to solve problem, and to think systematically and objectively. Teachers should be able to identify the basic competencies that students can achieve when learning using the integrated learning model. Good teachers are teachers who, in their teaching, attempt to apply the student-center learning approach [16].

Compared to conventional approaches, the integrated learning emphasizes more involvement of the student in the learning process or directing students to be actively involved in the learning process and decision making [14]. This integrated learning approach emphasizes the application of the concepts of learning by doing. In general, integrated learning principle focuses on developing students' competencies optimally, therefore it takes the active role of students in the learning process. Through integrated learning, students can increase their critical thinking skills [17].

Integrated learning is also a model of learning that involves multiple fields of study to provide a meaningful experience to the student [18]. In the integrated learning students can understand the concept they learn through direct experience and connect it with another concept they have already learnt [19].

The formulation of the problem is as follows: How to design an interactive e-module that integrates the themes of everyday life in a way that is valid, practical, and effective to improve the primary schools student's competency? The research aims to develop the interactive e-module based on integrated learning that can facilitate students in carrying out the learning process, so it can improve the student's competency. Interactive e-module is designed in the form of an electronic module using Adobe Flash CS6 software.

\section{RESEARCH METHOD}

\section{A. Type of Research}

This research used Research and Development of the 4-D model [20] that consisted of four stages: define, design, develop, and disseminate. At the define stage, three analyses were conducted: 1) the analysis of graduate competence standard, 2) the analysis of student learning difficulties, and 3) the analysis of teaching materials. At the design stage, the interactive e-module was designed following the steps of the integrated learning model. The next stage is the development to produce an interactive e-module that is valid, practical, and effective. Validity involved expert judgments. The practicality and effectiveness of the interactive e-module were obtained through the tryout of the interactive e-module to students. The last stage was the dissemination of the interactive e-module to primary school students in Padang, West Sumatra, Indonesia.

\section{B. Research Subject}

The research subject was an interactive e-module utilizing the integrated learning. The respondents in this research were 12 teachers and 70 primary schools students of Grade 5 consisting of 22 students at Primary School No. 51 Bungo Pasang, 23 students at Primary School No. 03 Alai, and 25 students Primary School No. 05 Sawahan during the second semester of the academic year 2020/2021.

\section{Research Instrument}

The instruments used to collect the data were interview guidance, observation sheets, questionnaire, student and 
teacher response questionnaire, test, attitude questionnaire, and skill assessment sheet. The interview guidance and observation sheets were used in the define stage. The student and teacher response questionnaire, test, attitude questioner, and skill assessment sheets were used in the develop stage. The student response questionnaire was used in the dissemination stage.

\section{Data Analysis Technique}

The analysis of the validity used the Aiken's V formula and the interactive e-module was declared valid if the value of $\mathrm{V}>0.60$. The analysis of the practicality used percentage formula and the interactive e-module was declared very practical if the average student and teacher response were 285.0. Meanwhile, the effectiveness analysis used the percentage formula and the interactive e-module was declared effective if the minimum learning completeness of the students was $85 \%$.

\section{RESUlTS AND DisCUSSION}

The results of research and development of the interactive e-module based on integrated learning focus on presenting the results of the define, design, develop, and disseminate stages.

\section{A. Define Stage}

At the define stage, the analysis of graduates competence standard, learning difficulties and teaching materials were conducted. The analysis of graduate competence standard shows its alignment with student competencies obtained in the learning process. This analysis consists of some indicators: attitude, knowledge, and skill.

The indicators of spiritual attitudes are categorized Good with a value of 77.78. Spiritual indicators still need to be included in the student book. This is done to avoid a decrease in spiritual attitudes in students and it is one of the most important domains of attitude in the 2013 curriculum. The indicators of social attitudes with a value of 64.58 are in the Middle Category. This means that student books require an increased content on social attitudes. The knowledge indicator with a value of 63.89 is in the Middle Category. This means that student books need to increase the content knowledge for students. The skill indicator scored 69.44 in the middle category. The results of student skills indicators show that students already have the skills when they graduate.

The analysis of the learning difficulty was conducted to determine the students' difficulties in learning the themes. The analysis was carried out from the aspects of using learning resources by students, student learning motivation, implementation of learning models and methods, and students' ability to understand the subject matter. Students find it difficult to find solutions to problems or tasks given in learning. The aaspects of motivation, methods, and learning resources are in Good Category. Whereas, the scores for the motivation aspect, method and the learning resources are $79.4,73.3$ and 70.8 respectively.

Learning in primary schools is carried out through an integrated learning, with the teaching materials based on some basic competencies. The teaching materials are organized based on the themes consisting of facts, concepts, principles, and procedures. Each lesson or unit includes competency knowledge, attitudes, and skills. Procedural knowledge has not been explained in details and is still in the form of discussion activities.

\section{B. Design Stage}

The results of the define stage conclude that the interactive e-module based on integrated learning can be designed in accordance with the structure of the interactive e-modules that have been determined, namely: cover, guide to using interactive e-modules, competencies to be achieved, the content of learning materials that include the learning objectives, learning activities (learning activities designed based on the step of integrated learning model), and exercises, evaluation, references, and author information. The captures of interactive e-modules can be seen in Figures 1 to 4 .

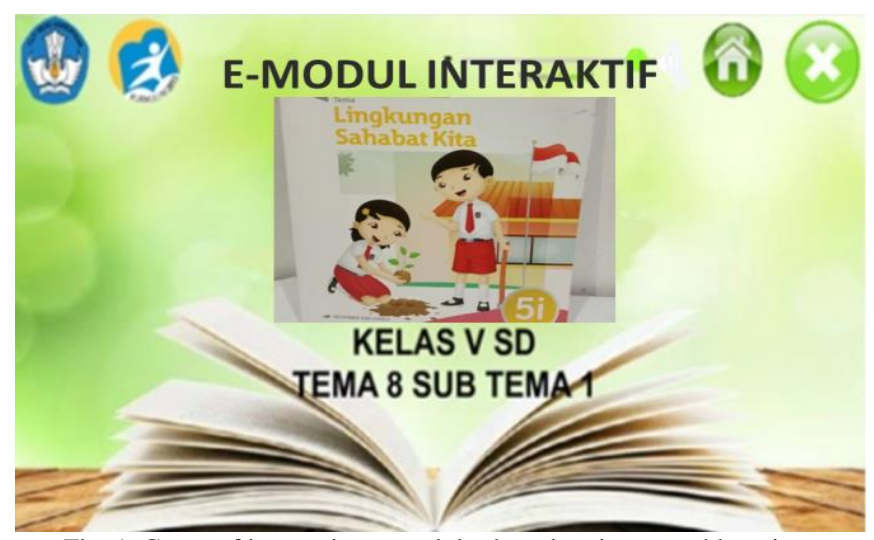

Fig. 1. Cover of interactive e-modules based on integrated learning.

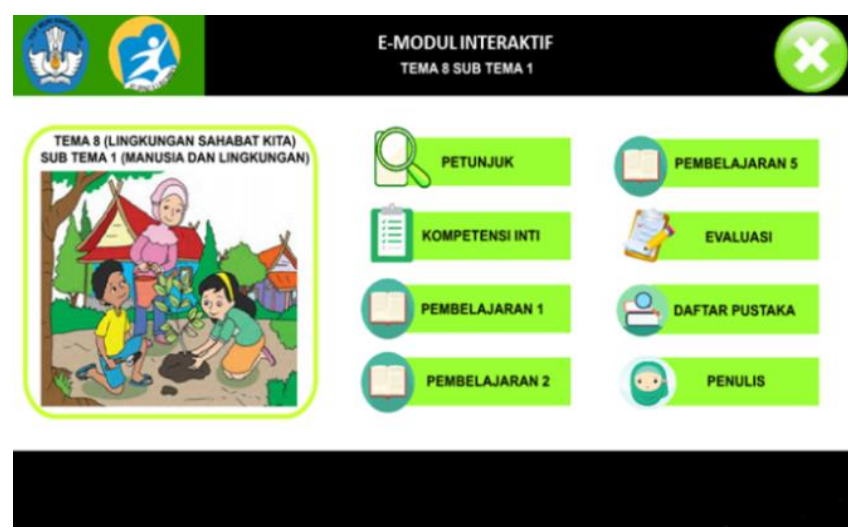

Fig. 2. Interactive e-modules menu.

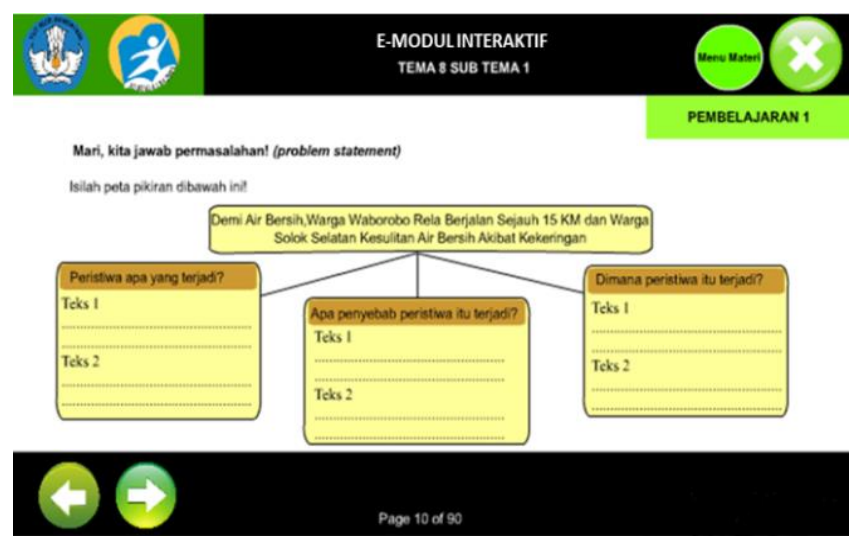

Fig. 3. Interactive e-modules exercise. 

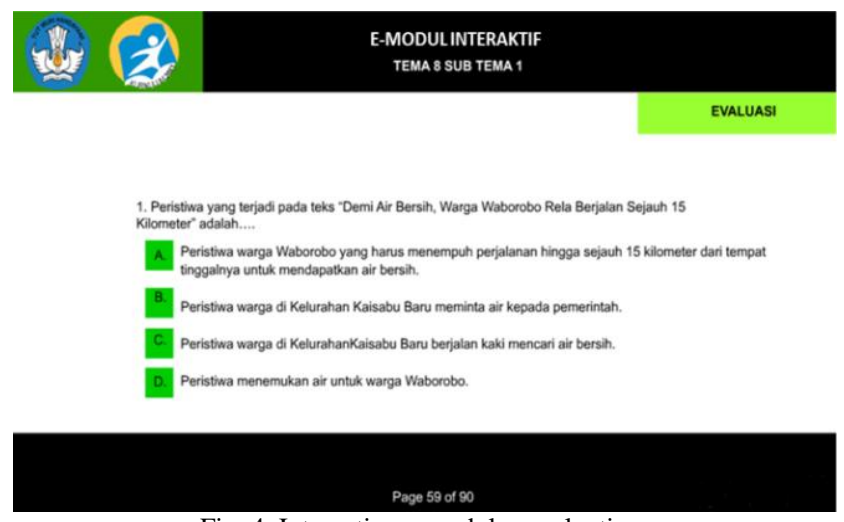

Fig. 4. Interactive e-modules evaluation.

\section{Develop Stage}

At the develop stage we conducted the test of validity, practicality, and effectiveness of the interactive e-module that has been developed. The interactive e-module validity was obtained through expert judgment who provided comments and feedback for revision. Then, the e-module was revised based on the advice of expert judgment. The results of the validity of the expert judgments for each component of the interactive e-module are presented in Table II.

TABLE II: VALIDITY RESULTS OF INTERACTIVE E-MODULE

\begin{tabular}{clcccccc}
\hline \multirow{2}{*}{ No. } & \multirow{2}{*}{ Validity Aspect } & \multicolumn{3}{c}{ Expert Judgment } & \multirow{2}{*}{ Average } & Category \\
\cline { 3 - 5 } & & 1 & 2 & 3 & & \\
\hline 1 & Content feasibility & 0.80 & 0.86 & 0.90 & 0.85 & Valid \\
2 & Construct feasibility & 0.92 & 0.85 & 0.89 & 0.89 & Valid \\
3 & Language feasibility & 0.73 & 0.67 & 0.86 & 0.75 & Valid \\
4 & Graphic feasibility & 0.75 & 0.82 & 0.95 & 0.84 & Valid \\
\hline \hline
\end{tabular}

The validity aspect of the interactive e-module is content, construct, language, and graphic feasibility. The average value of validity aspect is 0.83 and it falls within the valid category. The practicality and effectiveness tests of the interactive e-module were obtained through trying out the interactive e-module to some students. The results of the practicality of the interactive e-module are presented in Table III.

TABLE III: THE PRACTICALITY RESULTS OF INTERACTIVE E-MODULE

\begin{tabular}{llcc}
\hline \hline & & \multicolumn{2}{c}{ Average Response } \\
\cline { 3 - 4 } & Practicality Aspect & Teacher & Student \\
& & 86.80 & 89.40 \\
2 & Easy understand & 85.00 & 90.60 \\
3 & Interesting & 90.62 & 85.67 \\
\hline \hline
\end{tabular}

The practical aspect of the interactive e-module is interesting, efficient and easy to understand. The average response of the teacher is 87.47 which falls in the very practical category. The average response of students is 88.56 and falls in the very practical category. Therefore, it can be said that the interactive e-module based on integrated learning was very practical to be used by students. The effectiveness of interactive e-module is measured in terms of student competencies in the domain of knowledge, skills, and attitudes. The results of the student's competence in the knowledge domain are presented in Table IV.

The average competence of SD (Primary School) No. 03 students in the knowledge domain is 83.5 with learning completeness of $90 \%$. The average competence of SD 05 students in the knowledge domain is 85.8 with learning completeness of $87 \%$. The average competence of SD 51 students in the knowledge domain is 81.1 with learning completeness of $97 \%$. This shows that the interactive e-module is effective in terms of the knowledge domain. The results of the student competence in the skill domain are presented in Table V.

TABLE IV: THE AVERAGE of Students COMPETENCE IN THE KNOWLEDGE DOMAIN

\begin{tabular}{cccc}
\hline \hline \multirow{2}{*}{$\begin{array}{c}\text { Meeting } \\
\text { (Face to Face) }\end{array}$} & \multicolumn{3}{c}{ Primary School (SD) } \\
\cline { 2 - 4 } & SD 03 & SD 05 & SD 51 \\
\hline 1 & 80.0 & 82.0 & 78.5 \\
2 & 83.9 & 86.3 & 81.2 \\
3 & 86.6 & 89.2 & 83.6 \\
\hline \hline
\end{tabular}

TABLE V: STUDENTS'-COMPETENCES IN THE SKILL DOMAIN

\begin{tabular}{lrcc}
\hline \multirow{2}{*}{ Students Activities } & \multicolumn{3}{c}{ Primary School (SD) } \\
\cline { 2 - 4 } & SD 03 & SD 05 & SD 51 \\
\hline Prepare the tools & 86.8 & 83.6 & 83.9 \\
Assembling tools & 79.7 & 89.4 & 87.4 \\
The accuracy of using the tool & 87.8 & 88.5 & 83.9 \\
Collecting the data & 90.7 & 82.3 & 87.8 \\
Prepare the report & 83.7 & 87.9 & 82.7 \\
Presentation & 89.7 & 90.8 & 87.6 \\
\hline \hline
\end{tabular}

The average competence of SD (Primary School) No. 03 students in the skill domain was 86.4 with learning completeness of $87 \%$. The average competence of SD 05 students in the skill domain is 87.1 with learning completeness of $89 \%$. The average competence of SD 51 students in the skill domain is 85.6 with learning completeness of $85 \%$. This shows that the interactive e-module is effective in terms of the skill domain. The results of the student's competence in the attitudes domain are presented in Table VI.

TABLE VI: The STUDENTS COMPETENCE IN THE ATTITUdE DOMAIN

\begin{tabular}{lccc}
\hline \hline \multirow{2}{*}{\multicolumn{1}{c}{ Attitude Aspects }} & \multicolumn{3}{c}{ Primary School (SD) } \\
\cline { 2 - 4 } & SD 03 & SD 05 & SD 51 \\
\hline Curiosity about group activities & 85.3 & 87.6 & 89.0 \\
Careful in carrying out activities & 89.5 & 88.4 & 87.2 \\
Cooperation when carrying out & 97.8 & 98.5 & 85.9 \\
group activities & & & \\
\hline \hline
\end{tabular}

The average competency of SD (Primary School) No. 03 students in the attitude aspect is 90.9. The average competency of SD 05 students in the attitude domain is 91.5 . The average competence of SD 51 students in the attitude domain is 87.4 . This shows that the interactive e-module is effective in terms of the attitude domain.

\section{Disseminate Stage}

This stage was carried out after the interactive e-module developed is stated valid, practical, and effective. The interactive e-module was distributed in the form of google drive which was sent to students through the teachers at ten Primary Schools in West Sumatra. Based on the student response questionnaire to the interactive e-module, it was found that the interactive e-module was good and easy to learn.

\section{E. Discussion}


The interactive e-module based on integrated learning provides opportunities for students to be able to understand the relationship between teaching material from various fields of science and the everyday life of students. Modules that connect the learning materials with students' real life can increase students' interest and help students learn [21]. The interactive e-module is designed based on the needs analysis. The interactive e-module cover is equipped with images and attractive colours so that it can attract student reading interest The interactive e-module cover design has an influence over the students' reading interest [22]. The interactive e-module is designed with colours so that it is attractive to students and can strongly motivate them in learning [23]. The coloured interactive e-module can provide visualization for students in understanding learning material [24]. The success of learning depends on the success of the teacher in designing teaching materials [25]. Designing teaching material was carried out through teaching material analysis and determining themes. The theme chosen is related to students' real life, simple, interesting, and up to date based on the criteria of determining the themes in integrated learning.

The results of data analysis show that: 1) the validity of interactive e-module falls within the valid category based on expert judgment, 2) the practicality of interactive e-module is considered to be part of the very practical category based on the teacher and students' response, 3) the effectiveness of interactive e-module falls in the effective category based on the student learning outcomes from the aspects of knowledge attitudes, and skills that show improvement. The evaluation of the validity of the interactive e-module is based on its suitability with the compilation components. The valid interactive e-module contains compatibility between each of its components [26].

The interactive e-module has been included in the valid category because it has met four aspects, namely, the aspect of content feasibility, construct feasibility, language feasibility, and graphic feasibility [27]. The teaching material presented in the interactive e-module is related to the surrounding environment, which contains examples and images to encourage students to construct their knowledge and making it easier for the student to understand the lessons [28]. Presentation of teaching material has been arranged systematically, which involves students in learning, and helps students think systematically [29]. The steps of the interactive e-module follow the syntax of the integrated learning.

Based on the constructed aspect, the interactive e-module is in accordance with the standard interactive e-module writing criteria and is presented systematically. The relationship between teaching materials is well explained, each teaching material is presented systematically with descriptions, examples, and exercises. For presentation of the teaching material, examples and illustrations are needed to can help and facilitate students' understanding. The coherence of the content of the teaching material makes it easier for students to learn and it also guides students to get used to systematic thinking [29].

Based on the language aspect, teaching materials were developed according to the level of students' ability to understand the teaching material. The use of the right language is an important factor. The use of language includes choosing a variety of languages, choosing words, using effective sentences, and composing meaningful paragraphs. Even though the content of the teaching material is accurate, uses a consistent format, and is packaged in an attractive manner, if the language used is not understood by students, the teaching material will not be meaningful [29]. Good teaching materials are expected to motivate students to read, do assignments, and arouse students' curiosity to explore the teaching material. The interactive e-module has fulfilled the feasibility of the language, number of the sentence, number of words in the sentence, and grammar [30]. The use of language that is clearly and easily understood can create quality learning [31], [32].

The practicality of interactive e-module using the integrated learning model is judged by teacher responses and student responses. The interactive e-module practicality based on the teacher responses and students' responses is considered very practical. The interactive e-module is said to be very practical if the e-module can be used easily by the students [33]. The implementation of integrated learning makes it easier for the teachers to choose how to teach in accordance with the competencies expected of the students.

The practicality of interactive e-modules using the integrated learning model is judged by teacher responses and student responses. The interactive e-module falls in the very practical category. The implementation of integrated learning makes it easier for the teacher to choose teaching materials according to the competencies of the student. The interactive e-module based on integrated learning is easy to use which makes it very practical for students [33]. The interactivity provided in the interactive e-module helps students achieve better understanding and motivation [34].

The effectiveness test of interactive e-module shows the improvement of students' learning outcomes in terms of knowledge, skill, and attitude, such as honesty, piety, hard work, responsibility, discipline, independence, communication, curiosity, collaboration, and caring for the environment [35]-[40]. Integrated learning can improve the competence of students [41]-[45].

The competence of students in the cognitive aspect could increase as students could understand very well the materials in the interactive e-module. The students' learning mastery exceeded the target set by their respective schools. This indicates that the interactive e-module can facilitate a meaningful experience for the students. Interactive e-book indicated a large effect towards academic achievement [46]. The subject matter relates to the environment around the student. The integrated learning is a learning approach involving the relevance of themes or learning materials in several fields of study, with the aim of providing meaningful experiences to students [47].

The results of skill competency assessment were obtained from student activity while doing the practicum. The average learning outcomes in the skill domain falls in the good category. The interactive e-module is effective in improving student skills. This is because interactive e-module based on integrated learning can guide students in experimental activities and relate to everyday problems that are easy to identify. In addition, there are clear work procedures and 
questions that guide the achievement of goals. These activities were in the form of direct experience carried out by students so that it can improve students' skills [48].

Thematic learning models are effective in improving students' thinking skills in the cognitive, affective, and psychomotor aspects because thematic learning model activities can be interesting and memorable in making students think critically and creatively [49]. The learning conducted using the e-module was able to improve students' conceptual understanding [50]-[54].

The attitude competencies observed were curiosity about group activities, carefulness in carrying out activities, and cooperation when carrying out group activities. The students' curiosity can be increased by continuing to be trained and motivated to explore knowledge by asking in-depth questions and finding answers from various sources of information with teacher guidance [55]. The integrated learning can increase learning activity as well as improving students' positive behaviors [56]-[58].

The integrated learning occurs when the authentic event or exploration of a topic become the supporting devices in the curriculum [59]. Furthermore, in the implementation, students can be invited to be actively involved in exploring topics or events, students learn the process and content more than one of their study fields at a time. The integrated learning is a learning approach involving multiple fields of study [60]. This kind of learning approach is expected to provide students with meaningful experiences. In the integrated learning students gain an understanding of the concept they learn through direct experience and are able to relate them to another concept they had already understood. The integrated learning as an application of one learning strategy based on integrated curriculum approach that aims to make the learning process relevant and meaningful for the students [61]. With an integrated approach, students are encouraged to work in groups and learn from their own experiences.

\section{CONCLUSION}

This research has found the interactive e-module based on integrated learning. Interactive e-modules are developed using appropriate learning models. One way to facilitate students in learning is through an integrated learning model. Integrated learning uses themes to link between some subject content and the students' real-life experiences, to provide meaningful experiences to them. The interactive e-module based on integrated learning are found to be valid, practical, and effective for improving student competence in Primary School. Validity is measured based on expert judgments. The practicality was obtained through teachers and students' responses after teaching using interactive e-module. The effectiveness of interactive e-module was measured based on students' competency achievement at knowledge, skill, and attitude domain. In the knowledge domain, student's learning mastery has been achieved. In the integrated learning students gains an understanding of the concept they learn through direct experience and are to relate them to another concept they had already understood. The skill competencies of students observed were prepared the tools, assembling tools, the accuracy of using the tool, collecting the data, prepare the report, and presentation. The attitude competencies of students observed were curiosity about group activities, careful in carrying out activities, and cooperation when carrying out group activities.

\section{CONFLICT OF INTEREST}

We declare that there is no conflict of interest.

\section{AUTHOR CONTRIBUTIONS}

Risda Amini plays a role in determining the title of the research, the main problems of the research, preparing research proposals, conducting the research, and writing research report. Usmeldi plays a role as a data collector, data processor and analysis, and writing the manuscript of journal.

\section{ACKNOWLEDGMENT}

The authors thank the Rector of Universitas Negeri Padang for funding this research project.

\section{REFERENCES}

[1] T. N. Hopfenbeck, J. Lenkeit, Y. Masri, K. Cantrell, J. Ryan, and J.-A. Baird, "Lessons learned from PISA: A systematic review of peer-reviewed articles on the programme for international student assessment," Scandinavian Journal of Educational Research, vol. 62 , no. 3, pp. 333-353, 2018

[2] H. Retnawati, S. Munadi, J. Arlinwibowo, N. F. Wulandari, and E. Sulistyaningsih, "Teachers' difficulties in implementing thematic teaching and learning in elementary schools," The New Educational Review, no. 48, pp. 201-212, 2017.

[3] H Fitriani, D. Djamas, and A. Fauzi, "Textbook design of integrated science subject with integrated model in bio magnetic topic," Journal of Physics: Conference Series, vol. 1185, no. 012072, 2019.

[4] F. Farida, Y. Helsa, and Firman, "Developing integrated learning model for character education toward the implementation of curriculum 2013 in elementary school," in Proc. the 2nd SEA-DR, pp. 124-131, April 2014.

[5] K. R. Winatha and M. M. Abubakar, "The usage effectivity of project-based interactive e-module in improving students' achievement," Jurnal Pendidikan Teknologi dan Kejuruan, vol. 24, no. 2, pp. 198-202, October 2018.

[6] L. A. Hutahaean, S. Siswandari, and H. Harini, "Need analysis of the development of economics interactive e-module based on contextual teaching and learning for SMA," Budapest International Research and Critics in Linguistics and Education (BirLE) Journal, vol. 2, no. 2, pp. 343-350, May 2019.

[7] R. Sujanem, I. N. P. Suwindra, and I. Suswandi, "The effectiveness of problem-based interactive physics e-module on High School students' critical thinking," Journal of Physics: Conference Series, vol. 1503, no. $012025,2020$.

[8] N. R. Utami, A. Jufriadi, and H. D. Ayu, "Interactive e-module based on h-guided inquiry: optimize the ICT skills and learning achievements," Berkala Ilmiah Pendidikan Fisika, vol. 8, no. 3, pp. 183-195, 2020.

[9] N. M. A. Sari and I. B. S. Manuaba, "The development of interactive e-module based the inquiry of human's digestive system materials on theme three healthy food of fifth grade students," Indonesian Journal of Educational Research and Review, vol. 4, no. 1, pp. 54-62, 2021.

[10] W. Y. Hsiung, "Designing an interactive and engaging module sites using the RASA model," Preparing the Next Generation of Teachers for 21 st Century Education, Pennsylvania, USA: IGI Global, pp. 65-88, 2018 .

[11] Z. S. E. W. Abidin and S. E. Walida, "Interactive e-module model of transformation geometry based on CASE (Creative, Active, Systematic, Effective) as a practical and effective media to support learning autonomy and competence," Brazilian Journal of Implantology and Health Sciences, vol. 1, no. 7, pp. 206-223, 2019.

[12] B. D. D. Arianti and R. H. Wirasasmita, "WILMO (web-based interactive learning module), e-learning design for vocational school," Journal of Physics: Conference Series, vol. 1539, no. 012045, 2020. 
[13] E. Syafutri, W. Widodo, and Y. Pramudya, "Development of interactive physics e-module using the SETS (science, environment, technology, society) approach to improve science literacy dimension of content and process dimensions in fluid dynamics material," Indonesian Review of Physics, vol. 3, no. 1, pp. 11-18, June 2020.

[14] D. Jackson, "Developing pre-professional identity in undergraduates through work-integrated learning," Higher Education, vol. 74, no. 5, pp. 833-853, 2017.

[15] C. Wongwatkit, N. Srisawasdi, G.-J. Hwang, and P. Panjaburee, "Influence of an integrated learning diagnosis and formative assessment-based personalized web learning approach on students learning performances and perceptions," Interactive Learning Environments, vol. 25, no. 7, pp. 889-903, 2017.

[16] J. C. Marshall, J. B. Smart, and D. M. Alston, "Inquiry-based instruction: A possible solution to improving student learning of both science concepts and scientific practices," International Journal of Science and Mathematics Education, vol. 15, no. 5, pp. 777-796, 2017.

[17] N. Fazriyah, Y. Supriyati, and W. Rahayu, "The effect of integrated learning model and critical thinking skill of science learning outcomes," Journal of Physics Conference Series, vol. 812, no. 012014 2017.

[18] R. J. Riordan, Mi. J. Hine, and T. C. Smith, "An integrated learning approach to teaching an undergraduate information systems course," Journal of Information Systems Education, vol. 28, no. 1, pp. 59-70, 2017.

[19] F. F. Ke, S. Lee, and X. H. Xu, "Teaching training in a mixed-reality integrated learning environment," Computers in Human Behavior, vol. 62, pp. 212-220, 2016

[20] Thiagarajan, D. S. Semmel, and M. I. Semmel, Introductional Development for Training Teacher of Exceptional Children Leadership Training Institute, Special Education, Minnesota: University of Minnesota, Minneapolis, 1974, pp. 3-11.

[21] A. Kartikasari, Roemintoyo, and S. Yamtinah, "The effectiveness of science textbook based on science technology society for Elementary School level," International Journal of Evaluation and Research in Education (IJERE), vol. 7, no. 2, pp. 127-131, June 2018.

[22] W. Verlaan, J. Miller, and K. Ingraham, I'm a Boy and I Don't Like Pink! The Influence of Book Covers on Male Elementary Students' Text Selection, Texas Association for Literacy Education Yearbook: Building Momentum, 2014, Section 1, Chapter 4, no. 2, pp. 36-47.

[23] G. Noel, "Rapid prototyping: An educational extension of anatomy coloring textbooks," Journal of Human Anatomy \& Physiology, vol. 1 , no. 1, pp. 1-4. 2015.

[24] T. Meidina and A. Marsidi, "Development of picture book media based on local stories to improve reading comprehension skills of mentally retarded in SMALB students at SLB Negeri I Gowa," Prosiding Seminar Nasional LP2M UNM, pp. 984-988, 2019.

[25] Suarman, Hendripides, and N. Hikmah, "Development of innovative teaching materials through scientific approach," Journal of Educational Sciences, vol. 2, no. 2, pp. 14-22, 2018

[26] Suwatra, Wayan, A. Suyatna, and U. Rosidin, "Development of interactive e-module for global warming to grow of critical thinking skills," International Journal of Advanced Engineering, Management and Science, vol. 4, no. 7, pp. 543-549, July 2018.

[27] BSNP, Textbook Assessment Instruments of Biology Lessons in SMA/MA, Jakarta: Kemendikbud, 2014, pp. 45-53

[28] F. Su'udiah, I. N. S. Degeng, and D. Kuswandi, "Development of contextual-based thematic textbook," Jurnal Pendidikan: Teori, Penelitian, dan Pengembangan, vol. 1, no. 9, pp. 1744-1748, 2016.

[29] B. Tian, Teaching Material Development, Jakarta: Universitas Terbuka, 2003, pp. 23-47.

[30] S. P. T. Himala, M. Ibrahim, and H. Fitrihidajati, "Readability of textbook based on activity in biology ranging topic for $\mathrm{X}$ grade in Senior High School," BioEdu, vol. 5, no. 3, pp. 445-448, 2016.

[31] S. H. Priyanto, Standard Criteria of Textbook. Workshop Paper on Writing Textbooks for Lecturers of Kopertis VI, 2012, pp. 51-64.

[32] H. M. Wati, E. Susantini, and S. Y. Rahayu, "The validity of metacognitive based teaching materials on carbohydrate anabolism material," BioEdu, vol. 4, no. 3, pp. 957-962, 2015.

[33] Utami, N. Rohmah, A. Jufriadi, and H. D. Ayu, "Interactive e-module based on h-guided inquiry: optimize the ict skills and learning achievements," Berkala Ilmiah Pendidikan Fisika, vol. 8, no. 3, pp. 183-195, November 2020.

[34] Y. W. Li, "Transforming conventional teaching classroom to learner-centred teaching classroom using multimedia-mediated learning module," International Journal of Information and Education Technology, vol. 6, no. 2, pp. 105-112, February 2016.
[35] I. D. Pursitasari, S. Nuryanti, and A. Rede, "Innovative-thematic based integrated science learning on natural diversity theme to improve students'critical thinking skills in Junior High School," Unnes Science Education Journal, vol. 7, no. 2, pp. 140-145, July 2018.

[36] Y. Narti, P. Setyosari, I. N. S. Degeng, and W. D. Dwiyogo, "Thematic learning implementation in Elementary School (Phenomenology studies in SDN 01 Pamotan and SDN 01 Majangtengah Dampit Malang)," International Journal of Science and Research, vol. 5, no. 11, pp. 1849-1855, 2016.

[37] Chumdari, S. Anitah, Budiyono, and N. Suryani, "Implementation of thematic instructional model in Elementary School," International Journal of Educational Research Review, vol. 3, no. 4, pp. 23-31, 2018.

[38] E. W. Winarni, H. Lusa, and S. Dadi, "The impact of thematic learning integrated ICT in tabot Bengkulu as cultural ceremony toward social interaction knowledge in Elementary School," Asian Journal of Education and Training, vol. 4, no. 2, pp. 70-74, 2018.

[39] M. T. Wuryani, Roemintoyo, and S. Yamtinah, "Developing thematic textbooks based on character education at Elementary School," Elementary Education Online, vol. 17, no. 1, pp. 268-276, March 2018.

[40] A. Syamsuddin, R. Babo, Sulfasyah, and S. Rahman, "Mathematics learning interest of students based on the difference in the implementation of model of thematic learning and character-integrated thematic learning," European Journal of Educational Research, vol. 10, no. 2, pp. 581-591, 2021

[41] R. D. Puspita, D. Sunendar, B. Musthafa, and R. Agung. "Improving students reading comprehension ability through integrated thematic learning with school literacy movement support," Jurnal Pendidikan Humaniora, vol. 5, no. 3, pp. 99-103, 2017.

[42] S. E. Atmojo and W. Kurniawati, "Thematic learning model of science, environment, technology and society in improving elementary students' science literacy," Jurnal Pendidikan Indonesia, vol. 7, no. 1 , pp. 59-69, April 2018.

[43] L. Nurlaela, M. Samani, I. G. P. Asto, and S. C. Wibawa, "The effect of thematic learning model, learning style, and reading ability on the students' learning outcomes," IOP Conf. Series: Materials Science and Engineering, vol. 296, no. 012039, pp. 1-8, 2018.

[44] Marsono, Yoto, M. Devi, and S. S. Mustakim. "The development of the interdisciplinary thematic learning (INTEL) model in vocational education," Advances in Social Science, Education and Humanities Research, no. 379, pp. 338-342, 2019.

[45] Muhammad, S. E. Pramono, and Kustiono, "Development of integrative thematic learning models based on scientific approaches and 21st century learning skills," Educational Management, vol. 10, no. 1, pp. 119-209, April 2021

[46] B. C. Y. Lim, L. W. L. Liu, and C. H. Choo, "Investigating the effects of interactive e-book towards academic achievement," Asian Journal of University Education, vol. 16, no. 3, pp. 78-88, October 2020.

[47] S. R. Goldman, C. Snow, and S. Vaughn, "Common themes in teaching reading for understanding:" Lessons from three projects," Journal of Adolescent \& Adult Literacy, vol. 60, no. 3, pp. 255-264, 2016.

[48] V. Ashokan and K. Venugopal, "Impact of thematic approach on communication skill in preschool," Imperial Journal of Interdisciplinary Research, vol. 2, no. 10, pp. 394-397, 2016.

[49] N. Saputri, M. Khumaedi, and E. Supraptono, "Thematic learning models in competence body massage solus per aqua in vocational education institutions," Journal of Vocational and Career Education, vol. 4, no. 1, pp. 38-45, June 2019.

[50] D. I. Afifah, E. S. Rahayu, and Y. U. Anggraito, "Development of e-module based android for teaching material of plantae kingdom topic," Journal of Biology Education, vol.7, no. 1, pp. 1-8, April 2018

[51] A. Suyatna, H. Maulina, I. Rakhmawati, and R. A. N. Khasanah, "Electronic versus printed book: A comparison study on the effectivity of Senior High School physics book," Jurnal Pendidikan IPA Indonesia, vol. 7, no. 4, pp. 391-398, December 2018

[52] D. S. Sitorus, S. Siswandari, and K. Kristiani, "The effectiveness of accounting e-module integrated with character value to improve students' learning outcomes and honesty," Cakrawala Pendidikan, vol. 38, no. 1, pp. 120-129, February 2019.

[53] R. Adawiyah and L. Anwar, "Implementation of an interactive e-module to improve concept understanding of students," Advances in Social Science, Education and Humanities Research, no. 513, pp. 78-84, 2021.

[54] M. D. Permata and J. A. Safitri, "Developing an e-module physics-based kvisoft flipbook maker to enhance the concept of understanding for the senior high school student," Advances in Social Science, Education and Humanities Research, no. 541, pp. 495-501, 2021. 
[55] A. Wang, C. S. Chai, and S. Hairon, "Exploring the impact of teacher experience on questioning techniques in a knowledge building classroom," Journal of Computers in Education, vol. 4, no. 1, pp. 27-42, 2017.

[56] T. A. Baranova, E. Y. Tokareva, A. M. Kobicheva, and N. G. Olkhovik, "Effects of an integrated learning approach on students' outcomes in St. Petersburg Polytechnic University," in Proc. the 3rd International Conference on Digital Technology in Education, pp. 77-81, October 2019.

[57] T. Baranova, L. Khalyapina, A. Kobicheva, and E. Tokareva, "Evaluation of students' engagement in integrated learning model in a blended environment," Education Sciences, vol. 9, no. 2, pp. 1-13, June 2019.

[58] N. G. Nguyen, "Integrated teaching of extreme geometric problems in Vietnam," International Journal of Learning, Teaching and Educational Research, vol. 18, no. 8, pp. 168-191, August 2019.

[59] P. D. Lange, A. T. Neumann, P. Nicolaescu, and R. Klamma, "An integrated learning analytics approach for virtual vocational training centers," International Journal of Interactive Multimedia and Artificial Intelligence, vol. 5, no. 2, pp. 32-38, February 2018.

[60] S. Dallinger, K. Jonkmann, J. Hollm, and C. Fiege, "The effect of content and language integrated learning on students' English and history competences-Killing two birds with one stone?" Learning and Instruction, vol. 41, pp. 23-31, February 2016.

[61] N. Ain and R. Rahutami, "Theme network in thematic learning in elementary school," Journal of Physics: Conference Series, vol. 1013 no. $012065,2018$.
Copyright $\odot 2022$ by the authors. This is an open access article distributed under the Creative Commons Attribution License which permits unrestricted use, distribution, and reproduction in any medium, provided the original

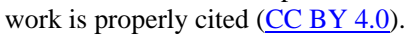

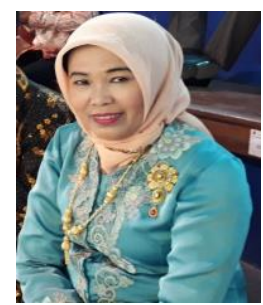

Risda Amini is an associate professor of Primary School Teacher Education Department of Universitas Negeri Padang, West Sumatera, Indonesia. She is currently as the head of science laboratory of Primary School Teacher Education Department. Her research interest are implementing technologies in teaching and learning in primary school, development of learning model, learning media and learning assessment.

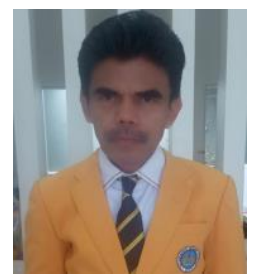

Usmeldi is a professor of physics education in electrical engineering department, Universitas Negeri Padang, West Sumatera, Indonesia. He is currently as the head of Physics Laboratory of Engineering Faculty. His research interest are development of physics learning model, natural science learning model, research based learning model, creative project based learning model and evaluation of technology and vocational learning. In addition, he is also actively as a reviewer in various international journals. 